\title{
SOSIALISASI DAN SIMULASI MITIGASI BENCANA GEMPA BUMI DALAM MENINGKATKAN KESIAPSIAGAAN SISWA SDN 2 WATES PONOROGO
}

\author{
Risma Dwi Arisona, M.Pd \\ Dosen Jurusan Tadris Ilmu Pengetahuan Sosial, Fakultas Tarbiyah dan Ilmu Keguruan, Institut \\ Agama Islam Negeri Ponorogo, Jl. Pramuka156, Po Box 116 Ponorogo 63471 \\ arisona@iainponorogo.ac.id
}

\begin{abstract}
ABSTRAK
Bencana gempa bumi terjadi secara tiba-tiba tanpa bisa diprediksi oleh manusia. Dengan mengetahui bahwa gempa bumi belum bisa diduga secara ilmiah, perlu dilakukan usaha mengurangi resiko akibat yang ditimbulkan gempa bumi. Penyebab banyaknya korban bencana gempa bumi karena kurangnya pengetahuan dan kesiapsiagaan bencana gempa bumi. Oleh karena itu, sosialisasi dan simulasi mitigasi bencana gempa bumi penting dilakukan sejak dini untuk memperkecil risiko menjadi korban melalui pendidikan bencana di sekolah. Pendidikan merupakan wahana yang efektif untuk membangun perilaku peserta didik dalam menghadapi bencana. Pengetahuan yang dimiliki peserta didik dapat memengaruhi sikap kesiapsiagaan bencana gempa bumi. Penelitian ini bersifat penelitian praktik dengan batasan masalah melalui pemberian materi dan pelatihan simulasi mitigasi bencana gempa bumi. Hasil penelitian menunjukkan bahwa: 1) Materi yang disampaikan menarik, terdapat ilmu yang sangat berarti tentang jenisjenis bencana, simbol-simbol bencana, dan prosedur kesiapsiagaan sebelum, saat terjadi, dan setelah kejadian bencana gempa bumi; 2) Menambah pengetahuan dan keterampilan dalam penyelamatan diri bila terjadi gempa bumi; 3) Melatih reflek dalam melakukan langkah-langkah penyelamatan diri bila tiba-tiba terjadi gempa bumi, 4) Meningkatkan kesiapsiagaan akan bencana gempa bumi bagi siswa sekolah dasar dan guru.
\end{abstract}

Kata Kunci: mitigasi, gempa bumi, kesiapsiagaan

\begin{abstract}
Earthquake disasters occur suddenly without being able to be predicted by humans. By knowing that earthquakes cannot yet be scientifically predicted, efforts should be made to reduce the risk of the consequences of the earthquake. The cause of the large number of victims of earthquake disasters due to lack of knowledge and earthquake disaster preparedness. Therefore, it is important to socialize and simulate earthquake mitigation early to minimize the risk of becoming a victim through disaster education in schools. Education is an effective vehicle for building student behavior in the face of disasters. Knowledge possessed by students can influence the attitude of earthquake disaster preparedness. This research is a practical research with limitation of the problem through the provision of material and training in earthquake disaster mitigation simulation. The results showed that: 1) The material presented was interesting, there was very significant knowledge about the types of disasters, disaster symbols, and preparedness procedures before, when they occurred, and after the earthquake disaster; 2) Adding knowledge and skills in self-rescue in the event of an earthquake; 3) Practicing reflexes in taking steps to save themselves when an earthquake suddenly occurs, 4) Increasing earthquake preparedness for elementary school students and teachers.
\end{abstract}

Keywords: mitigation, earthquake, preparedness 


\section{PENDAHULUAN}

Letak geografi Indonesia berada pada pertemuan 3 tiga lempeng, yaitu Indo-Australia di bagian Selatan, Eurasia dicbagian Barat dan Utara, dan Pasifik di bagian Timur. Secara umum, Indonesia berada di daerah cincin api yang terbentang dari Pulau Sumatera, Jawa, Bali, Nusa Tenggara, Sulawesi, Maluku, dan Papua. ${ }^{1}$ Oleh karena itu, wilayah Indonesia sangat rawan terhadap bencana gempa bumi. Beberapa kejadian gempa bumi yang terjadi di wilayah Indonesia besar maupun keci, antara lain: tahun 2004 gempa bumi di Sumatera, tahun 2006 gempa bumi di Yogyakarta, dan tahun 1976 dan 1979 gempa bumi di Bali. ${ }^{2}$

Bencana gempa bumi tersebut telah membuka mata semua elemen masyarakat untuk mewaspadai bencana ini. Bencana gempa bumi terjadi secara tiba-tiba tanpa bisa diprediksi oleh manusia. Dengan mengetahui bahwa gempa bumi belum bisa diduga secara ilmiah, perlu dilakukan usaha mengurangi resiko akibat yang ditimbulkan gempa bumi. Usaha-usaha yang dilakukan untuk mengurangi resiko gempa bumi disebut Mitigasi Bencana Alam Gempa Bumi. $^{3}$

Faktor utama penyebab banyaknya korban bencana gempa bumi rendahnya pengetahuan tentang kesiapsiagaan bencana gempa bumi. Korban bencana rata-rata di dominasi wanita dan anak-anak. Oleh karena itu, sosialisasi dan simulasi mitigasi bencana gempa bumi sejak dini kepada masyarakat yang rentan bencana serta kesiapsiagaannya sangat penting untuk menghindari atau memperkecil risiko menjadi korban.

Sosialisasi dan simulasi mitigasi bencana gempa bumi perlu dikembangkan mulai tingkat pendidikan dasar untuk meningkatkan kesiapsiagaan bencana gempa bumi sejak dini. Belajar dari serinya kejadian gempa bumi di Indonesia, maka sosialisasi dan simulasi mitigasi gempa bumi wajib dilakukan. Hal tersebut dilakukan untuk menghidari korban jiwa dari bencana tersebut.

Sosialisasi dan simulasi mitigasi bencana gempa bumi di sekolah dasar membantu peserta didik dalam melakukan penyelamatan untuk diri sendiri dan masyarakat pada saat

\footnotetext{
${ }^{1}$ Departemen Energi dan Sumber Daya Mineral (tt). Pengenalan Gempabumi. Vulcanological Survey of Indonesia (VSI).

${ }^{2}$ Lilik Kurniawa, Ridwan Yunus, Mohd. Robi Amri, dan Narwawi Pramudiarta, Indek Rawan Bencana Indonesia, Badan Nasional Penanggulangan Bencana (BNPB), 2011.

${ }^{3}$ Subagia, I Wayan dan I G.L Wiratma, Mitigasi Becana Alam Gempa Bumi, Makalah Disampaikan dalam Seminar Nasional Research Inovatif (Seminar-1) yang dilaksanakan oleh Lembaga Penelitian UNDIKSHA, 2013.
} 
terjadi bencana. Memasukkan pendidikan bencana ke dalam kurikulum sekolah sangat membantu dalam membangun kesadaran siswa dan masyarakat tentang isu tersebut. ${ }^{4}$

Berdasarkan hasil observasi di SDN 2 Wates Ponorogo yang dilaksanakan pada tanggal 29 Juli 2019 menunjukan belum pahamnya seluruh warga sekolah (kepala sekolah, guru, dan siswa) akan bahaya dan pengurangan resiko bencana gempa bumi. Hal ini disebabkan belum pernah adanya sosialisasi dan simulasi bencana gempa bumi di sekolah ini. Selain itu, tidak masuknya pendidikan kebencanaan dalam kurikulum di sekolah.

Pendidikan bencana secara khusus belum masuk ke dalam kurikulum sekolah di Indonesia. ${ }^{5}$ Keadaan tersebut bertentangan dengan Hyogo Framework yang disusun oleh PBB yang menyebutkan bahwa pendidikan siaga bencana merupakan prioritas, yaitu: Use knowledge, innovation and education to build a culture of safety and resilience at al levels. Pendidikan mitigasi bencana telah diterapkan diberbagai dunia, anatar lain Bangladesh, Iran, India, Mongolia, Filipina, Turkey, dan Tonga. ${ }^{6}$

Pendidikan merupakan wahana yang efektif untuk membangun perilaku peserta didik dalam menghadapi bencana. Pendidikan dan simulasi mitigasi bencana dapat meningkatkan pengetahuan dan kesiapsiagagan warga sekolah dalam menghadapi bencana khususnya bencana gempa bumi. Berdasarkan latar belakang tersebut, peneliti melakukan penelitian yang berjudul: "Sosialisasi dan Simulasi Mitigasi Bencana Gempa Bumi dalam Meningkatkan Kesiapsiagaan Siswa SDN 2 Wates Ponorogo".

\section{METODE PENELITIAN}

Penelitian ini merupakan jenis penelitian kualitatif yang bersifat penelitian praktik dengan batasan masalah melalui pemberian materi dan pelatihan simulasi mitigasi bencana Gempa Bumi. Sosialisai dan simulasi melibatkan seluruh warga sekolah yang terdiri dari 1 kepala sekolah, 5 guru, dan 52 siswa - siswi mulai kelas 1 sampai 6 SDN 2 Wates Ponorogo. Kegiatan dilaksanakan pada tanggal 14 Agustus 2019 yang bekerjasama antara IAIN Ponorogo dengan Tagana Dinas Sosial Kabupaten Ponorogo dan Tagana Dinas Sosial Provinsi Jawa Timur.

Metode pelaksanaan sosialisai dan simulasi mitigasi bencana gempa bumi dalam penelitian ini dibagi atas tiga tahap,yaitu persiapan/observasi, pelaksanaan, dan evaluasi.

\footnotetext{
${ }^{4}$ Supriyono, Primus, Seri Pendidikan Pengurangan Risiko Bencana Gempabumi, Yogyakarta: C.V ANDI Offset, 2014,

${ }^{5}$ Kemdikbud, Kurikulum 2013 Kompetensi Dasar Sekolah Dasar (SD)/ Madrasah Ibtidaiyah (MI), Kementrian Pendidikan dan Kebudayaan, Jakarta, 2013.

${ }^{6}$ UNCRD, Mengurangi Kerentanan Anak-anak Sekolah terhadap Bahaya Gempa Bumi, Proyek Inisiatif Keselamatan Sekolah Terhadap Gempa Bumi (SESI), 2009.
} 
Tahap pertama persiapan, melakukan observasi awal dengan pihak sekolah bertujuan untuk mengetahui sejauh mana pengetahuan siswa-siswi tentang mitigasi bencana gempa bumi.

Tahap kedua pelaksanaan sosialisasi dan simulasi bencana gempa bumi. Pelaksanaan sosialisasi mitigasi bencana dengan memberikan pengetahuan dasar tentang jenis-jenis bencana, simbol-simbol bencana, dan prosedur kesiapsiagaan sebelum, saat terjadi, dan setelah kejadian bencana gempa bumi dengan menggunakan gambar.

Tahap ketiga evaluasi sosialisasi dan simulasi bencana gempa bumi. Tahap ini adalah melakukan evaluasi kegiatan ini. Evaluasi ini dilaksanakan untuk mengetahui seberapa paham siswa-siswi ini tentang bencana gempa bumi dengan memberikan umpan balik berupa pertanyaan-pertanyaan langsung setelah kegiatan sosialisasi dan simulasi kitigasi bencana gempa bumi.

\section{HASIL DAN PEMBAHASAN}

Pelaksanaan kegiatan sosialisasi dan simulasi mitigasi bencana gempa bumi dalam meningkatkan kesiapsiagaan siswa SDN 2 Wates Ponorogo dilaksanakan pada hari Rabu tanggal 14 Agustus 2019. Berdasarkan pengamatan langsung dan wawancara dengan pihak kepala sekolah, guru, dan siswa setelah kegiatan yang dilakukan terungkap bahwa kegiatan ini sangat bermanfaat karena telah memberikan pengetahuan dasar tentang jenis-jenis bencana, simbol-simbol bencana, dan prosedur kesiapsiagaan sebelum, saat terjadi, dan setelah kejadian bencana gempa bumi melalui gambar. Peserta berharap kegiatan ini dapat dilanjutkan secara terus-menerus dan lebih optimal lagi.

Secara umum, seluruh warga sekolah yang terdiri dari 1 kepala sekolah, 5 guru, dan 52 siswa - siswi mulai kelas 1 sampai 6 SDN 2 Wates Ponorogo dalam melaksanakan simulasi gempa bumi sangat bersungguh-sungguh dalam mengikuti kegiatan, baik dalam mendengarkan informasi maupun dalam melakukan praktik-praktik yang diberikan. Materi sosialisasi bencana yang disampaikan, yaitu jenis-jenis bencana, simbol-simbol bencana, dan prosedur kesiapsiagaan sebelum, saat terjadi, dan setelah kejadian bencana gempa bumi melalui gambar. Informasi disampaikan dengan metode tanya jawab. Praktik-praktik yang dilakukan selama pelatihan antara lain prosedur kesiapsiagaan sebelum, saat terjadi, dan setelah kejadian bencana gempa bumi secara langsung.

Pada awal kegiatan, instruktur pelatihan mitigasi bencana gempa bumi dari Tagana Dinas Sosial meberikan materi pengenalan jenis-jenis bencana dan simbol-simbol bencana. Siswa terlihat terlihat antusias saat instruktur memberikan materi. Hal ini ditunjukkan dengan 
banyaknya siswa yang menjawab pertanyaan-pertanyaan yang disampaikan. Keadaan tersebut bertambah antusias ketika yang menjawab benar siswa mendapatkan hadiah.

Sebelum pelaksanaan simulasi gempa bumi, siswa- siswi diberikan pengenalan terhadap rambu-rambu jalur evakuasi gempa bumi. Hal ini bertujuan agar siswa tidak bingung ketika simulasi bencana. Selain itu, agar siswa dapat mempratikkan simulasi bencana gempa bumi dengan baik dan benar. Kegiatan pengenalan rambu-rambu jalur evakuasi.

Pada saat kegiatan simulasi mitigasi bencana gempa bumi yang dipandu Instruktur dari Tagana Dinas Sosial diikuti antusias oleh siswa-siswi SDN 2 Wates Ponorogo. Instruktur memberikan contoh-contoh terlebih dahulu tentang tahapan-tahapan yang dilakukan saat simulasi mitigasi bencana gempa bumi. Tahapan saat terjadi gempa bumi tersebut, antara lain: jangan panik, lindungi organ-organ vital dengan tangan/barang di sekitar, keluar ruangan, dan berkumpul di titik kumpul atau tempat aman. Penjelasannya sebagai berikut.

1. Janngan panik

Saat terjadi gempa bumi usahakan tidak panik. Jika kita panik akan tambah memperkeruh suasana dan tidak dapat melindungi diri dengan baik.

2. Lindungi organ-organ vital dengan tangan/barang di sekitar

Saat terjadi gempa bumi lindungi organ vital seperti kepala dengan tangan atau benda sekitar. Mislanya: siswa dapat melindungi kepalanya dengan tas sekolah yang mereka bawa.

3. Keluar ruangan

Pada saat keluar ruangan, orang yang deka pintu keluar harus segera keluar, kemudian dahulukan anak-anak, lansia, dan wanita saat keluar pintu.

4. Berkumpul di titik kumpul atau tempat aman

Ikuti rambu-rambu jalur evakuasi agar kita segera berada pada daerah yang aman terhadap bencana gempa bumi. Selain itu, berkumpul di titik kumpul akan memudahkan petugas evakuasi untuk segera mengevakuasi kita.

Kegiatan simulasi mitigasi bencana gempa bumi dilaksanakan di dalam dan luar kelas. Kegiatan simulasi mitigasi bencana gempa bumi diikuti dengan baik dan tertib oleh seluruh siswa. Tampak bahwa siswa sudah mampu melakukan penyelamatan diri saat terjadi gempa. Hal tersebut dapat dilihat dari kecepatan mereka menerima dan mengikuti petunjuk yang diberikan. Misalnya, ketika mereka dilatih untuk berlindung di bawah meja saat terjadi gempa, dalam waktu singkat mereka bisa melakukannya dengan baik. Selain itu, ketika 
mereka berlari menyelamatkan diri mereka mengikuti rambu-rambu jalur evakuasi dengan baik.

Berdasarkan wawancara dan pengamatan langsung di lapangan pada akhir kegiatan, diperoleh informasi sebagai berikut:

1. Materi yang disampaikan menarik, terdapat ilmu yang sangat berarti tentang jenis-jenis bencana, simbol-simbol bencana, dan tata cara dan prosedur kesiapsiagaan sebelum, saat terjadi, dan setelah kejadian bencana gempa bumi.

2. Menambah pengetahuan dan keterampilan dalam penyelamatan diri bila terjadi gempa bumi.

3. Melatih reflek dalam melakukan langkah-langkah penyelamatan diri bila tiba-tiba terjadi gempa bumi.

4. Meningkatkan kesiapsiagaan akan bencana gempa bumi bagi siswa sekolah dasar dan guru.

\section{PENUTUP}

Hasil penelitian sosialisasi dan simulasi mitigasi bencana gempa bumi dalam meningkatkan kesiapsiagaan siswa SDN 2 Wates Ponorogo menunjukkan bahwa: 1) Materi yang disampaikan menarik, terdapat ilmu yang sangat berarti tentang jenis-jenis bencana, simbol-simbol bencana, dan prosedur kesiapsiagaan sebelum, saat terjadi, dan setelah kejadian bencana gempa bumi; 2) Menambah pengetahuan dan keterampilan dalam penyelamatan diri bila terjadi gempa bumi; 3) Melatih reflek dalam melakukan langkahlangkah penyelamatan diri bila tiba-tiba terjadi gempa bumi, 4) Meningkatkan kesiapsiagaan akan bencana gempa bumi bagi siswa sekolah dasar dan guru.

Kegiatan Sosialisasi dan Simulasi Mitigasi Bencana Gempa Bumi dalam Meningkatkan Kesiapsiagaan Siswa SDN 2 Wates Ponorogo sangat bermanfaat bagi peserta karena memberikan pengetahuan teoritis dan praktek tentang mitigasi bencana gempa bumi. Hal ini akan meningkatkan kesiapsiagaan terhadap bencana alam terutama gempa bumi di sekolah dasar sehingga diharapkan mampu meminimalkan dampak negatif dari gempa bumi. Kegiatan ini sebaiknya lebih sering dilakukan dan melibatkan komunitas sekolah yang lebih banyak.

\section{DAFTAR PUSTAKA}

Departemen Energi dan Sumber Daya Mineral (tt). Pengenalan Gempabumi. Vulcanological Survey of Indonesia (VSI). 
Lilik Kurniawa, Ridwan Yunus, Mohd. Robi Amri, dan Narwawi Pramudiarta. 2011. Indek Rawan Bencana Indonesia, Badan Nasional Penanggulangan Bencana (BNPB).

Kemdikbud. 2013. Kurikulum 2013 Kompetensi Dasar Sekolah Dasar (SD)/ Madrasah Ibtidaiyah (MI). Jakarta: Kementrian Pendidikan dan Kebudayaan.

Subagia, I Wayan dan I G.L Wiratma. 2013. Mitigasi Becana Alam Gempa Bumi. Makalah Disampaikan dalam Seminar Nasional Research Inovatif (Seminar-1) yang dilaksanakan oleh Lembaga Penelitian UNDIKSHA.

Supriyono, Primus. 2014. Seri Pendidikan Pengurangan Risiko Bencana Gempabumi. Yogyakarta: C.V ANDI Offset.

UNCRD. 2009. Mengurangi Kerentanan Anak-anak Sekolah terhadap Bahaya Gempa Bumi. Proyek Inisiatif Keselamatan Sekolah Terhadap Gempa Bumi (SESI). 